\title{
Linking Household Source of Water to Child Health Technology: Evidence from 2004-2011 Cameroon Demographic and Health Survey
}

Mbu Daniel Tambi*

Department of Agricultural Economics, University of Dschang, Cameroon

\begin{abstract}
This study is caption 'Household Source of Water and Child Health Outcomes: Evidence from 2004-2011 Cameroon Demographic and Health Survey'. Contaminated source of water use for bathing, washing, drinking as well as in the preparation of food and poor hygienic environment are a major nuance to human health especially child health. To contribute in solving this problem, we shall examine the following objectives: (1) explore the determinants of household water supply, (2) quantify the effects of water source on child health outcomes; 3 ) decompose the water child health effects on child age 0 to 59 months; and (4) derived policy implication on the basis of our analysis. Methodologically, we will use the pool data of the third and fourth Cameroon demographic and health survey collected in 2004 and 2011 respectively after the 1991 and 1998 data. The 2SLS and ivprobit model that takes care of the endogeneity problem is used to estimate our results in STAA 11.0. Our result shows that factors such as parent literacy, breast feeding mothers, male household head; household social status, household size and urban residence are strong determinants of household source of water. We also observed that a marginal change in water supply will result to a corresponding increase in child health. Other factors positively associated with child health increase due to water effects include: household size, urban household residence. Child health of age 24 and 36 months is strongly affected by source of water supply. Other factors positively affecting children's health of age 24 to 36 months are household size and place of residence. In terms of policy, we recommend that decision makers through the ministry of public health should intensify child health - good water supply campaigns, as well as to increase the supply of good drinking water following the WHO standards. This is a major step towards economic growth and poverty reduction in the different regions of Cameroon.
\end{abstract}

Keywords: Household; Source of water; Child health; 2004/2011 DHS; Cameroon

\section{Introduction}

Contaminated source of water use for bathing, washing, drinking as well as in the preparation of food and poor hygienic environment are a major nuance to human health especially child health. A country's productive capacity is strongly determine by the health quality of the population, it's therefore imperative to examine the intricacies, determinants and issues surrounding this area of study [1]. Fundamentally, countries located around the equator are heavily characterize by: high irregular rainfall during the wet season; high rate of sun shine in the dry season; many streams, lakes, rivers, standwater, springs, swamps; forest and savannah zones as well as irregular hamattan winds. All these may either make or mar human health depending on the nature of the environment. Cameroon located around the equator and in the heart of Africa seems to suffer from these characteristics. She experience irregular rainfall that have provoke swamps and stand waters due to heavy runoff and poor infiltration in the forest zones. These have created an environment that favours the growth of harmful insects (such as mosquitoes, tsetse fly, midges, scorpions, centipedes) and insect-borne diseases (such as flea, tick, mosquito, and louse borne diseases). These have resulted to illnesses such as malaria, river blindness, filariasis, ross river fever, plague, leishmaniasis, dandy fever and chagas diseases to name a few. All these diseases have ultimately reduces human life especially in the forest and coastal lands of Cameroon.

Due to climate change, the irregular nature of rainfall has resulted to the production of toxic water, hence humans using this water to bath, drink and watch domestic utensils consequently contact the diseases such as cholera, diarrhea, dysentery which all weakens the human system making it vulnerable as well as increasing health expenditure that also weakens the socioeconomic status of Cameroonians. Generally, waterborne diseases are caused by pathogenic microorganisms that most commonly are transmitted in contaminated fresh water. Infection commonly results during bathing, washing, drinking, preparation of food, or the consumption of food. Various forms of waterborne diarrhea diseases probably are the most prominent examples, and affect mainly children in developing countries; according to the WHO [2] such diseases account for an estimated $4.1 \%$ of the total daily life years global burden of disease, and cause about 1.8 million human deaths annually. The World Health Organization estimates that $88 \%$ of that burden is attributable to unsafe water supply; sanitation and hygiene (Table 1).

In real terms, an unfavourable environment is a dilemma to its inhabitance. The rationale of this issue is that the Cameroon labour market, needs men and women that are sound in health and who can rightly contribute to increase productivity, growth and the reduction of poverty. Therefore, from the foregoing, one can clearly observed that water source strongly influences human life, especially child health as they are fragile in nature. Further, Bastian noted that waterborne diseases can have a significant impact on the economy both locally and internationally. People who are infected by a waterborne disease are

*Corresponding author: Mbu Daniel Tambi, Department of Agricultural Economics, University of Dschang, Cameroon, Tel: 23769702 8116; E-mail: tambimbu@yahoo.co.uk

Received October 31, 2017; Accepted December 04, 2017; Published December 06, 2017

Citation: Tambi MD (2017) Linking Household Source of Water to Child Health Technology: Evidence from 2004-2011 Cameroon Demographic and Health Survey. Int J Econ Manag Sci 6: 486. doi: 10.4172/2162-6359.1000486

Copyright: @ 2017 Tambi MD. This is an open-access article distributed under the terms of the Creative Commons Attribution License, which permits unrestricted use, distribution, and reproduction in any medium, provided the original author and source are credited. 


\begin{tabular}{|c|c|c|}
\hline Disease and transmission & Microbial agent & Sources of agent in water supply \\
\hline \multicolumn{3}{|l|}{ Bacterial infections } \\
\hline Cholera & Vibrio cholera & Drinking water contaminated with the bacterium \\
\hline Dysentery & Shigella and Salmonella & Water contaminated with the bacterium \\
\hline Typhoid fever & Salmonella typhi & Ingestion of water contaminated with feces of an infected person \\
\hline \multicolumn{3}{|l|}{ Parasitic infections } \\
\hline Taeniasis & Tapeworms of the genus (Taenia) & Drinking water contaminated with eggs \\
\hline Ascariasis & Ascaris lumbricoides & Drinking water contaminated with feces containing eggs \\
\hline Guinea Worm Disease (Dracunculiasis) & Dracunculus medinensis & Stagnant water containing larvae, generally in parasitized Copepoda \\
\hline \multicolumn{3}{|l|}{ Viral infections } \\
\hline Hepatitis A & Hepatitis A virus (HAV) & Can manifest itself in water (and food) \\
\hline Poliomyelitis (Polio) & Poliovirus & Enters water through the feces of infected individuals \\
\hline Severe Acute Respiratory Syndrome (SARS) & Corona virus & Manifests itself in improperly treated water \\
\hline \multicolumn{3}{|l|}{ Protozoal infections } \\
\hline Amoebiasis (hand-to-mouth) & Protozoan (Entamoeba histolytica) & Sewage, non-treated drinking water, flies in water supply. \\
\hline Cyclosporiasis & Protozoan parasite (Cyclospora cayetanensis) & Sewage, non- treated drinking water \\
\hline Giardiasis (fecal-oral) (hand-to-mouth) & $\begin{array}{l}\text { Most common intestinal parasite (Protozoan } \\
\text { Giardia lamblia) }\end{array}$ & $\begin{array}{l}\text { Untreated water, poor disinfection, pipe breaks, leaks, ground water } \\
\text { contamination, campgrounds where humans and wildlife use same } \\
\text { source of water. }\end{array}$ \\
\hline
\end{tabular}

Table 1: Sources of microbial agent in household water supply and disease transmission.

usually confronted with related costs and seldom with a huge financial burden. The financial losses are mostly caused by the costs for medical treatment and medication, costs for transport, special food, and by the loss of manpower. Many families must even sell their land to pay for treatment in a proper hospital. On average, a family spends about $10 \%$ of the monthly households' income per person infected.

As noted in UNICEF [3] one of the principal millennium development goal (MDGs) states that by 2015, half the people without sustainable access to safe drinking water and basic sanitation should be satisfied. However, until date this objective is still far to be a reality in Cameroon. The quality of water is a major health input, thus achieving this MDG will have a significant impact on achieving many of the other MDGs such as poverty and hunger, universal primary education, gender and equality, reduced child mortality, combating diseases (HIV, malaria) and global partnership. The household water supply is very important for human existence in five reasons: (1) water is vital for health, (2) water leads to social development, (3) water is a good economic investment, (4) water helps the environment and (5) water is achievable. The table below illustrates the different diseases human can derive from both water source and the environment as experience in Cameroon.

The United Nation Children's Fund (UNICEF) revealed that where adequate sanitation is provided coupled with protected water and improved hygiene behaviours one can expect the following improvement: (1) lower morbidity rates in the population, (2) lower mortality rates due to diarrhea, (3) better nutrition among children, (4) cleaner environment, (5) safer food and increased impact of improved water supplies, (6) better learning and retention among school children, (7) more dignity and privacy for everybody especially women and girls and increased awareness of the importance of sanitation and hygiene and the need to develop a more permanent strategy. Hence, water and hygiene are keys to child survival, development and growth, though improved water supply has yet to reach 2.6 billion people in the developing world, almost 980 million of which are children under 18 years old, this means that millions of children are dying each year from preventable diseases. In rural Cameroon, the stakes are still high, thousands of children are hospitalized each month and many are dying because of water borne diseases and the environmental sanitation.
Thus, the world health organization reported that almost one tenth of the global disease burden could be prevented by improving water supply and management of water resources while in another report they noted that $4 \%$ of all deaths and $5.7 \%$ of total disability-adjusted life years can be attributed to water [4]. Cheng et al. [5] added that, world wide 1.4 million children die each year from preventable diarrhea diseases and some $88 \%$ of diarrhea cases are related to unsafe water. Further, water has been described as the most effective public health intervention the international community has at its disposal to reduce child mortality. Hence, because of the great potential to improve child health through targeted interventions in the environment in a context where countries have limited resources to invest in better water, making it important to provide an evidence-based estimate on the benefit of this factor [6].

Sambe-Ba [7] noted that diarrhea diseases remain one of the principal causes of childhood mortality and morbidity in low income countries despite significant progress in our understanding of the pathogenesis of these diseases and in their management. According to the World Health Organization, diarrhea disease is the second leading cause of death in children under five years old worldwide, and is responsible for 1.5 million child deaths every year. Thus, Schiller [8] indicated that the risk of contacting diarrhea diseases is currently 5 -fold higher in Sub-Saharan Africa (SSA) than in industrialized countries.

With particular attention to Cameroon, despite the economic growth relative to the region, is facing a familiar string of environmental problems which are tightly connected to socio-economic factors that afflict the population, such as loss of natural habitat, poaching, desertification, overfishing and Diseases. Among these diseases in Cameroon, many children are dying of pneumonia (19\%), diarrhea $(18 \%)$, malaria $(8 \%)$, neonatal sepsis or pneumonia $(10 \%)$, preterm delivery (10\%) and asphyxia at birth (8\%) and other diarrhea related diseases [9].

Despite the pressing need for appropriate policies, document and disseminate knowledge in this area, it should be noted that research on child health issues vis-a-vis nutrition, mother's employment, fertility, age and education, inequality has been well documented but issues of water source-hygiene and child health outcomes using evidence based estimate has not yet been exploited. Most of the studies in this 
area so far as Cameroon is concern, has instead examine the role of microbial agents in contaminated water that causes diarrhea diseases or the epidemiology of rotavirus diarrhea in children under 5 years, such authors include: Ndze et al. [10], Yongsi and Ntouda et al. [11] mean while the issue of water supply and child health are well develop in other countries with the same economic and social strata like Cameroon. Some of the authors include: Bampoke and Sambe-ba et al. in the case of Senegal, Aryal et al. [12] in the case of Nepal, Brainerd and Menon for India and Roushdy et al. [13] for the case of Egypt to name a few.

This study is therefore bridging this gap in that we attempt to link the household source of water to child health outcomes, the study is also very important because it seems to be the first to use the Cameroon DHS to quantify the relationship between household source of water and child health outcomes in Cameroon. Hence, to do this, we will examine the following objectives: (1) explore the determinants of household water supply in Cameroon (2) the impact of household source of water on child Health outcomes in Cameroon; (3) decompose the effects of water source in child age 0 to 59 months; (4) derive policy implications on the basis of our analysis.

\section{Literature Review}

Yongsi evaluated health risks in the usage of contaminated drinking-water and its relationship with the prevalence of diarrhea diseases in Yaoundé, Cameroon. Using a cross-sectional epidemiological design of 3,034 households with children aged less than five years, revealed a diarrhea prevalence of $14.4 \%$ in children. Among various risk factors examined, water-supply modes and quality of drinking-water were statistically associated with diarrhea cases while levels of diarrhea attacks varied considerably from one neighbourhood to the other. Further, Yongsi found that diarrhea illnesses remain one of the principal causes of global childhood mortality and morbidity and concluded that diarrhea diseases and their spatial distribution are important tools for public health management and control strategic planning in Cameroon.

In the same line, Sambe-Ba examined the epidemiological and microbiological aspects of Community-acquired diarrhea among children and adults in urban, Senegal and realized that viral infection was significantly more frequent in children under five years old during the dry season. Bacteria and parasites were equally noted to be frequent in all age groups. There was equally a seasonal variation of bacterial infections during the study period, with a higher proportion of infections being bacterial and due to Salmonella spp. in particular, during the rainy season. This study suggests that in urban settings in Senegal, rotavirus is the principal cause of pediatric diarrhea during the dry season and that the proportion of bacterial infections seems to be higher during the rainy season.

Moe et al. [14] evaluated four bacterial indicators of tropical drinking-water quality (faecal coliforms, Escherichia coli, enterococci and faecal streptococci) and their relationship to the prevalence of diarrhea disease in a population of 690 under-2-year-olds in Cebu, Philippines. E. coli and enterococci were better predictors than faecal coliforms of the risk of waterborne diarrhea disease. They noted that little difference was observed between the illness rates of children drinking good quality water (less than 1 E. coli per $100 \mathrm{ml}$ ) and those drinking moderately contaminated water (2-100 E. coli per $100 \mathrm{ml}$ ). Children drinking water with greater than 1000 E. coli per $100 \mathrm{ml}$ had significantly higher rates of diarrhea disease than those drinking less contaminated water. They concluded that in developing countries where the quality of drinking-water is good or moderate other transmission routes of diarrhea disease may be more important; however, grossly contaminated water is a major source of exposure to faecal contamination and diarrhea pathogens.

Gundry et al. [15] intimated that in developing countries, the microbial contamination of household drinking water is implicated in the prevalence of various diseases, generally diarrhea and cholera, and their relationship with water quality at point-of-use. For cholera, a clear relationship was found with contaminated water. Home water treatment and storage interventions were also found to reduce cholera. For diarrhea, no clear relationship was found with point-of-use water quality, although interventions did significantly reduce diarrhea incidence. Ntouda determines the influence of access to drinking water on the health of populations in SSA, using data from Cameroon, Senegal and Chad DHS. Based on their study, it is clear from their descriptive analysis that $60 \%$ (Cameroon) and 59\% (Chad) of the cases of childhood diarrhea are due to the consumption of dirty water. In terms of explanatory analysis, they noted that when a household in Cameroon, Senegal or Chad does not have access to drinking water, children under 5 years old residing there are respectively $1.29,1.27$ and 1.03 times more likely to have diarrhea than those residing in households with easy access to drinking water.

Aryal observed that the incidence of diarrhea per 1000 population was found to be the highest in spring without toilet with 204.89 followed by Tube well without toilet with 145.30 , while it was less in Tap water with toilet with 46.05 . With respect to the burden of disease, Aryal also found it to be the highest in spring without toilet and the lowest in Tap water with toilet. Aryal realized that the households didn't treat water before drinking while hand washing practice was found to be more than $90 \%$ regardless of toilet availability. Thus, he argued that, there is greater risk of acquiring diarrhea disease and higher burden of disease in situation of unprotected water source and absence of toilet shows that these are still important contributing factors for diarrhea disease in Nepal. The use of sanitary toilets and protected water source are the important measures for diarrhea disease prevention in Nepal.

\section{Theoretical Framework and Methodological Setting}

In this framework, the economic model of the family developed by Becker [16] and as applied by Frijters et al. [17] forms the conceptual basis for our analysis of the consequences of household source of water (HSW) on child health (capture by child ill/death due to diarrhea diseases (CDD)). This relationship can be described within the framework of a simple household production model of child health for family $i$, as follows:

$$
C D D_{i}=\lambda_{1} \chi_{i}+\delta_{1} H S W_{i}+\varepsilon_{1 i}
$$

Where $\mathrm{CDD}_{\mathrm{i}}$ is a binary variable representing child $i$ 's ill/death due to diarrhea as the parent used or gave contaminated water to the child, $\chi_{\mathrm{i}}$ is a vector of (1) household characteristics such as place of residence, socioeconomic status and household size; (2) parental characteristics with variables such as: fertility rate, literacy, prenatal care, birth interval and marital status of mother and (3) child characteristic such as age of the child as well as sex of the child. The $H S W_{i}$ is household source of water and $\varepsilon_{i}$ is a random error term. The coefficient $\delta_{1}$ is the parameter of primary interest and represents the impact that the household source of water has on child health in Cameroon using the demographic and health survey data. Considering this single equation, the Probit estimates may be upward or downward biased depending upon the effect that child health has on household source of water and 
on the correlation between omitted variables and household source of water. In rural Cameroon, parents always do their best to give their ill child protected water; however with regards to children in good health, they don't care much on the source of water. Thus, if household source of water has a positive impact on child health, then we would expect the Probit estimate of $\delta_{1}$ to be biased upward.

As observed with the case of rural Cameroon, the prime difficulty of the two-way causality that comes in the effect on household source of water and child health may cause the classical endogeneity problem. To avoid the strong likelihood of this endogeneity bias, confounded by the problem of variables that is missing in empirical data, we use a two stage least squares (2SLS) estimation approach. Thus, the first-stage equation in this approach is:

$$
H S W_{i}=\beta_{1} \chi_{i}+\alpha_{1} T W S_{i}+\pi_{1 i}
$$

Where by TWS is tap water supply (use as an instrument to solve for the endogeneity problem); let us note that the 2SLS model captures the causal effect of household source of water for those households whose children's health is affected by protected tap water source. Importantly, though $H S W_{i}$ is ordinal, 2SLS estimates of $\delta_{1}$ can be interpreted as estimating the average marginal effect of a unit increase in $H S W_{i}$ for children whose health is affected by the supply of tap water. Before presenting the 2SLS estimates, we present a reduced form analysis of household source of water; here we would expect to observe mothers with death children or children suffering from diarrhea diseases to have lower supply of protected tap water. The reason is because children suffering from diarrhea diseases are negatively affected by poor household source of water. The 2SLS estimation allows us to scale the probit marginal effects into the effects on an increase in our ordinal household source of water measure [18].

As indicated earlier, we use household tap water as an instrument to overcome this endogeneity problem between household source of water and child health outcomes which cannot be adequately controlled for by observable characteristics. Assuming that household tap water is a valid instrument, we will use the ivprobit model (probit model controlling for endogeneity) which better respects the binary nature of child health (child death attributed to diarrhea diseases) as represented by the following two equations:

$$
\begin{aligned}
& C D D^{*}=\lambda_{2} \chi_{i}+\delta_{2} H S W_{i}+\varepsilon_{2 i} \\
& H S W_{i}=\beta_{2} \chi_{i}+\alpha_{2} T W S_{i}+\pi_{2 i}
\end{aligned}
$$

Where $C D D_{i}$ denotes actual child health and $C D D_{i}^{*}$ represents desired child health, note that $C D D_{i}=1$ if $C D D^{*}>0$ and zero otherwise, and the error terms $\varepsilon_{2 i}$ and ${ }_{2 i}$ follow a bivariate normal distribution with non-zero correlation.

\section{Analysis}

To estimate the result of this study, we will use the pool data of the third and fourth Cameroon demographic and health survey collected in 2004 and 2011 respectively after the 1991 and 1998 data. The 2011 DHS was aimed at a national representative sample of about 11732 children while in 2004 there were 8,125 children of 0-59 months with women of reproductive age, alive and living within the selected zones of sample as well as a sub sample of about $50 \%$ of households for the men. The results of these surveys were presented for Cameroon, Yaounde and Douala (two great metropolitan cities), other towns, urban and rural zones and each of the 12 areas of study constituting the 10 regions plus Douala and Yaounde. The outcome variable of the study is child health capture by child death attributed to diarrhea diseases; this variable is coded ' $h 11$ ' for those children of age 0 to 59 months that had diarrhea at the time of data collection.

The principal endogenous variable influencing child health is household source of water. This variable is coded ' $v 113$ ' and known as source of drinking water in the demographic and health survey in Cameroon. The various modalities associated to this variable are: (i) piped into dwelling, (ii) piped to yard/plot, (iii) public tap/standpipe, (iv) tube well or borehole, (v) protected well, (vi) unprotected well, (vii) protected spring, (viii) unprotected spring, (ix) river/dam/lake/ ponds/stream/canal/irrigation, (x) rainwater, (xi) cart with small tank, (xii) bottled water and other. The potential instrument use to solve the endogeneity problem is 'tap water in the household'.

The covariates or exogenous demographics to be use are: fertility rate, literacy, prenatal care, birth interval, marital status of mother, age of child, sex of child, place of residence, socioeconomic status and household size. Owing to Cheng et al, in this study, under-five mortality/death rate is defined as the probability of a child born in a specific year or period dying before reaching the age of five year per 1000 live births, if subject to age-specific mortality rates of that period. Cheng et al. also noted that the proportion of under-five deaths due to diarrhea is estimated by the WHO based on the causes of death in countries and recorded by the civil (vital) registration system.

\section{Expected Results}

In this section, we present (a) the weighted sample descriptive statistics; the results of the: (b) the determinants of household source of water; (c) impact of household source of water on child Health outcomes in Cameroon; (d) decompose the effects of water source on child age as well as (e) verify water source effects on socioeconomic status.

\section{Weighted sample descriptive statistics}

Table 2 presents the results of the weighted sample descriptive characteristics. Considering the full sample statistics, we observed that about $18.2 \%$ of children were ill or death due to diarrhea diseases in Cameroon in the period 2004/2011, this is especially true in rural Cameroon where most of the communities lack basic amenities such as good water supply. The basic water supply for drinking, cooking and washing/bathing include: rain water, collected mostly during the wet season, unprotected springs and wells, flowing streams and rivers as well as few open lakes. These sources of water constitute the most impure sources for human consumption with little or no treatment before consumption. It's often said in these communities that 'if you can't get what you want then manage what you have'. Based on these one can be tempted to say the biological system of the inhabitance of these areas is immune to the water supply especially for the matured rural dwellers. These evidences are demonstrated in the Table 2.

From Table 2, the mean water source is 24.76 however only about $4.7 \%$ of households have tap water in their homes, this figure seem right in the sense that only $40 \%$ of the households lives in urban centers with a total household size of 10.47 headed by male with a total of $86 \%$. Among these households, about $54 \%$ are non-poor and endow with a literacy rate of $42.8 \%$ with children ranging from 0 to 59 months of age. The birth interval of households in Cameroon following the 2004/2011 DHS is 29.32 giving a fertility rate of $37 \%$ with about 89.4 mothers engage in antenatal care, 54.7 consciously breast feeding their children. In this, $88 \%$ of the women are married while $68 \%$ are currently participating in the job market. 


\begin{tabular}{|c|c|c|c|c|c|c|}
\hline \multirow[t]{2}{*}{ Variable } & \multicolumn{2}{|c|}{ Full Sample } & \multicolumn{2}{|c|}{ Female Children } & \multicolumn{2}{|c|}{ Male Children } \\
\hline & Mean & SDV & Mean & SDV & Mean & SDV \\
\hline Child health (child ill/death due to diarrhea diseases) & 0.182 & 0.386 & 0.176 & 0.381 & 0.187 & 0.390 \\
\hline Household Source of Water & 24.769 & 13.059 & 24.770 & 13.026 & 24.769 & 13.093 \\
\hline Water at home ( $1=$ household has tap water, 0 otherwise ) & 0.047 & 0.211 & 0.049 & 0.217 & 0.044 & 0.205 \\
\hline $\begin{array}{l}\text { Mother breast feeding ( } 1=\text { mother breast feed the child, } 0 \\
\text { otherwise) }\end{array}$ & 0.547 & 0.497 & 0.553 & 0.497 & 0.542 & 0.498 \\
\hline Fertility rate & 4.370 & 2.658 & 4.353 & 2.619 & 4.388 & 2.697 \\
\hline Participation (1=mother currently working, 0 otherwise) & 0.681 & 0.465 & 0.682 & 0.465 & 0.680 & 0.466 \\
\hline Marital status ( $1=$ mother is married, 0 otherwise) & 0.881 & 0.323 & 0.884 & 0.319 & 0.878 & 0.326 \\
\hline Prenatal care ( $1=$ mother attended prenatal, 0 otherwise) & 0.894 & 0.306 & 0.891 & 0.311 & 0.898 & 0.301 \\
\hline Birth Interval & 29.327 & 24.110 & 29.458 & 24.467 & 29.192 & 23.739 \\
\hline Male ( $1=$ male headed household, 0 otherwise) & 0.859 & 0.347 & 0.860 & 0.346 & 0.857 & 0.349 \\
\hline Literacy (1=parent literate, 0 otherwise ) & 0.428 & 0.494 & 0.432 & 0.495 & 0.424 & 0.494 \\
\hline Child age in years $(0-5$ years $)$ & 1.827 & 1.388 & 1.821 & 1.389 & 1.834 & 1.386 \\
\hline Social status ( $1=$ parent non-poor, 0 otherwise) & 0.540 & 0.498 & 0.537 & 0.498 & 0.543 & 0.498 \\
\hline Household size & 10.479 & 6.201 & 10.483 & 6.151 & 10.476 & 6.251 \\
\hline Household Size Square & 148.276 & 213.977 & 147.725 & 210.233 & 148.841 & 217.758 \\
\hline Household residence (1=urban residence, 0 otherwise) & 0.401 & 0.490 & 0.396 & 0.489 & 0.407 & 0.491 \\
\hline Total Observation & \multicolumn{2}{|c|}{19857} & \multicolumn{2}{|c|}{9983} & \multicolumn{2}{|c|}{9874} \\
\hline
\end{tabular}

Source: Author; NB: SDV=Standard deviation.

Table 2: Weighted sample descriptive characteristics.

The sample statistics of female children reveal that in a total of 9983 observations, $17.6 \%$ of the female children were ill or died because of diarrhea or diarrhea related diseases. While in a sample of 9874 observations about $17.7 \%$ of male children suffered from diarrhea or diarrhea related diseases. The values of the male and female children are fairly the same, depicting the fact that diarrhea is a major problem for all the children and so a cause for concern for all families with children. The percentage for other variables are equally fairly the same, however, many male children seem to be born in the urban centers as compared to the female and with a bigger household size. This can be explain by the higher survival rate of children in urban zones due to either better water supply or medical facilities, the favourable maternal and paternal characteristics such as better education, wealth and prenatal care contribute to reduce or avoid diarrhea disease.

\section{Determinants, water source and child health effects}

The section analysis the determinants of water supply in Cameroon, child health technology and household source of water effects.

The determinants of the source of household water supply: As seen in Table 3 below, the result of the first stage least square reveals that parent literacy is a strong determinant of household source of water. The fact is that, educated people are well informed so they understand the value of health. Hence the tendency is for more educated people to adopt every precautionary measure to get the best water in to the house. This is also confirmed by mothers currently participating in the job market. Mother's naturally as the primary caretakers of children, will always sacrifice a greater portion of their resources being time or finances to ensure that their children are in good health. In rural Cameroon it's common to find father's abandoning the burden of children to their mother's this may partially cause by cultural and social reasons especially where both parent are uneducated.

Breast feeding mothers are conscious of the quality of water their children are consuming and so they will prefer to buy refine canned water in the case of Cameroon we have canned water (such as Tangui, Supermont, Volcanic, Seme etc) or water treated with chlorine. Even in the most remote village in Cameroon, mothers with breast feeding children are conscious of the effects of water on children some of them may go as far as to use Eau de Javel to treat water they give to their children. The consciousness of women is also explained by the health mass campaign conducted by the ministry of public health concerning diseases such as diarrhea, typhoid and malaria. This is the same case with mothers' fertility rate, birth interval and child age of zero to fifty nine months.

From the first stage least square result, we observed that water source correlates with male headed households. Whenever a household is headed by a male, the tendency is for the family income to increase especially when the couples are both working. Hence, in such homes the probability is very high for the parent to be aware of the importance of water supply to children. Today, the slogan 'prevention is better than cure' is known by most parents in Cameroon talk less of the educated and working class.

Other determinant factors negatively correlating with water source are household social status especially non-poor households, household size and urban residence. The result seems to be a reversal of what ought to be, however this is not the case; non poor households located in rural community in Cameroon where the water is not good enough for consumption will be bound to consumed impure water and vise versa. Thus the whole issue of sources of water strongly relies on the place of habitation. Critically, there are places by nature with good drinking water supply whereas in others their water is very poor. For instance the Buea community of Cameroon naturally has pure water originating from the impermeable rocks of mount Fako, this water flowing in the form of a spring needs little treatment to meet the WHO standards of good drinking water.

This result explains why urban residence and tap water are negatively correlating with water source. The problem is not living in an urban milieu or having tap water in the house but the question is; how good is the water for consumption. In towns such as Douala, kumba, Dschang, Tombel if water is not preserved in the fridge it's difficult to drink it confidently because of the taste and colour the water has. The argument is not that the fridge removes the taste or colour but that the temperature at which this water is store can eliminate every germ or 
Citation: Tambi MD (2017) Linking Household Source of Water to Child Health Technology: Evidence from 2004-2011 Cameroon Demographic and Health Survey. Int J Econ Manag Sci 6: 486. doi: 10.4172/2162-6359.1000486

Page 6 of 8

\begin{tabular}{|c|c|c|c|c|}
\hline \multirow[t]{2}{*}{ Variable } & \multicolumn{4}{|c|}{ Estimation Methods } \\
\hline & \multirow{2}{*}{$\begin{array}{c}\text { FSLS } \\
\text { Water Source }\end{array}$} & PROBIT & IV (2SLS) & IVPROBIT \\
\hline & & \multicolumn{3}{|c|}{ Child health (child ill/death due to diarrhea diseases) } \\
\hline Household Source of Water & $\mathrm{n} / \mathrm{a}$ & $0.001(0.61)$ & $0.004^{* * *}(2.68)$ & $0.015^{\star \star}(2.29)$ \\
\hline $\begin{array}{l}\text { Mother breast feeding ( } 1=\text { mother breast feed the child, } 0 \\
\text { otherwise) }\end{array}$ & $0.559^{* * *}(3.07)$ & $-0.075^{\star \star \star}(-3.17)$ & $-0.016^{\star \star *}(-2.73)$ & $-0.082^{* * *}(-3.46)$ \\
\hline Fertility rate & $0.201^{\star * \star}(5.57)$ & $-0.014^{\star \star \star}(-2.95)$ & $-0.006^{\star \star \star}(-5.21)$ & $-0.017^{\star * \star}(-3.45)$ \\
\hline Participation ( $1=$ mother currently working, 0 otherwise) & $0.985^{\star * *}(5.33)$ & $-0.037(-1.57)$ & $-0.012^{* *}(-2.03)$ & $-0.059^{* *}(-2.29)$ \\
\hline Marital status ( $1=$ mother is married, 0 otherwise) & $-0.377(-1.36)$ & $0.018(0.51)$ & $0.017^{*}(1.94)$ & $0.020(0.57)$ \\
\hline Prenatal care ( $1=$ mother attended prenatal, 0 otherwise) & $-0.399(1.39)$ & $-0.221^{* * *}(-6.10)$ & $-0.069^{\star \star \star}(-7.39)$ & $-0.213^{\star * \star}(-5.86)$ \\
\hline Birth Interval & $0.006^{*}(1.69)$ & $-0.000(-0.46)$ & $0.000(0.13)$ & $-0.000(-0.54)$ \\
\hline Male ( $1=$ male headed household, 0 otherwise) & $1.887^{\star * *}(7.39)$ & $0.066^{\star \star}(2.10)$ & $0.013(1.48)$ & $0.044(1.34)$ \\
\hline Literacy ( $1=$ parent literate, 0 otherwise ) & $0.530^{* * *}(2.68)$ & $-0.157^{\star \star \star}(-6.21)$ & $-0.055^{\star \star *}(-8.63)$ & $-0.157^{* * *}(-6.24)$ \\
\hline Child age in years ( $0-5$ years $)$ & $0.115^{\star}(1.78)$ & $-0.101^{* * *}(-11.35)$ & $-0.023^{* \star *}(-11.19)$ & $-0.101^{* * *}(-11.28)$ \\
\hline Social status ( $1=$ parent non-poor, 0 otherwise) & $-4.328^{* \star *}(-18.78)$ & $-0.187^{* \star *}(-6.24)$ & $-0.024^{* *}(-2.34)$ & $-0.116^{* \star}(-2.55)$ \\
\hline Household size & $-0.229^{\star * \star}(-5.36)$ & $0.032^{\star \star \star}(5.06)$ & $0.011^{\star \star *}(8.14)$ & $0.035^{\star \star *}(5.48)$ \\
\hline Household Size Square & $0.007^{\star \star *}(6.40)$ & $-0.001^{* \star * *}(-2.81)$ & $-0.000^{* \star *}(-6.88)$ & $-0.001^{* * *}(-3.25)$ \\
\hline Household residence ( $1=$ urban residence, 0 otherwise) & $-6.356^{* \star *}(-28.44)$ & $0.043(1.42)$ & $0.038^{\star \star *}(2.91)$ & $0.144^{* *}(2.51)$ \\
\hline Water at home ( $1=$ household has tap water, 0 otherwise ) & $-8.323^{* * *}(-20.42)$ & $-0.126^{* *}(-2.13)$ & $\mathrm{n} / \mathrm{a}$ & $\mathrm{n} / \mathrm{a}$ \\
\hline Constant term & $27.887^{* \star *}(53.37)$ & $-0.624^{* * *}(-9.01)$ & $0.141^{* * *}(2.94)$ & $-1.048^{* * *}(-5.28)$ \\
\hline $\mathrm{R}^{2} /$ (uncensored $\mathrm{R}^{2} /$ Pseudo $\mathrm{R}^{2}$ & 0.8256 & 0.0271 & 0.1916 & $\mathrm{n} / \mathrm{a}$ \\
\hline Partial R²(on excluded instruments) & $\mathrm{n} / \mathrm{a}$ & $\mathrm{n} / \mathrm{a}$ & $416.96(1,19842 ; 0.0000)$ & $\mathrm{n} / \mathrm{a}$ \\
\hline $\begin{array}{l}\text { Joint } F / X^{2} \text { ( } p \text {-value) test for Ho: coefficients on instruments }=0 / \\
\text { Wald/chi2 }\end{array}$ & $\begin{array}{l}349.95(14,19842 \\
0.0000)\end{array}$ & $474.54(15 ; 0.0000)$ & $41.88(14,19842 ; 0.0000)$ & $487.85(4 ; 0.0000)$ \\
\hline $\begin{array}{l}\text { Weak identification test: Cragg-Donald F-Stat ( } 5 \% \text { maximal IV } \\
\text { relative bias)/rho }(\rho)\end{array}$ & $\mathrm{n} / \mathrm{a}$ & $\mathrm{n} / \mathrm{a}$ & $416.961(16.38)$ & $-0.176(0.081)$ \\
\hline $\begin{array}{l}\text { Sargan statistic (overidentification test of all instruments): (Chi- } \\
\mathrm{sq}(2) \mathrm{P} \text {-val)/sigma }(\sigma)\end{array}$ & $\mathrm{n} / \mathrm{a}$ & $\mathrm{n} / \mathrm{a}$ & $0.000(0.000)$ & $11.755(0.058)$ \\
\hline $\begin{array}{l}\text { Durbin-Wu-Hausman } x^{2} \text { test for exogeneity of variables in (a) } \\
\text { ( } p \text {-value) above/Wald test of exogeneity }\end{array}$ & $\mathrm{n} / \mathrm{a}$ & n/a & $7.455(0.0003)$ & $4.57(0.0002)$ \\
\hline Observations & & & 19857 & \\
\hline
\end{tabular}

Source: Computed by author using pooled data of $2004 / 2011$ survey and STATA 11.0 . Notes: ${ }^{* * *}$, ${ }^{* *}$ and * indicate $1 \%, 5 \%$ and $10 \%$ levels of significance. N/B: Dependent variable is child ill/death due to diarrhea diseases; absolute value of robust t-statistics in parentheses beneath estimates, $n / a=n o t$ applicable.

Table 3: Water source effects on child health and determinants of source of water.

bacterial contained in the water. The household size is also important in determining this phenomenon of source of water supply effects and child health in Cameroon.

Concluding on the determinants of water supply using the Cameroon Demographic and Health survey, we observed that factors such as: parent literacy, working mothers, male household heads, breast feeding children, fertility rate, birth interval, social status, household size, place of residence are very important.

Child health technology and household source of water effects: Table 3 present the results of (a) first stage least square in column one (FSLS) as analyze above, this actually portray the determinants of the source of household water supply; (b) the probit result in column two (PROBIT), which can either be bias upward or downward; (c) the instrumental variable result in column three (IV 2SLS) while (d) the probit model controlling for endogeneity in column four (IVPROBIT).

Considering equation one above, the result of the probit regression can either be biased upward or downward depending on the direction of the relationship between water supply and child health effects. Therefore, this probit result is not appropriate for inference, this explain why the water source is insignificant revealing that the value of water source is not appropriate for judgment. The 2SLS result solve the problem of endogeneity resulting from the data this can either be from missing variables or omission whereas the IVPROBIT resolve the problem of endogeneity originating from both the data and elsewhere, hence the estimates of IVPROBIT is our preferred result. Further, following the joint $\mathrm{F} /(\mathrm{p}$-value) test for Ho: coefficients on instruments $=0 / \mathrm{Wald} / \mathrm{chi} 2$ of $41.88[14,19842$; 0.0000] for 2SLS and 487.85 [ $4 ; 0.0000]$ for IVPROBIT reveals that the probit result controlling for endogeneity is preferable.

Considering therefore, the IVPROBIT result, we observed that a marginal change in water supply will result to a corresponding increase in child health of $1.5 \%$. This result reveals that the source of water supply is a strong determinant of child health of age 0 to 59 months; this is consistent with that obtained by the World Health Organization. They reported that almost one tenth of the global disease burden could be prevented by improving water supply and management of water resources while in another report they noted that $4 \%$ of all deaths and $5.7 \%$ of total disability-adjusted life years can be attributed to water. As seen above, Cheng et al. added that, worldwide 1.4 million children die each year from preventable diarrhea diseases and some $88 \%$ of diarrhea cases are related to unsafe water.

The other factors positively associated with child health include: household size, urban household residence, while factors negatively associated with child health include; mothers currently employed in the job market, breast feeding children, fertility rate, mother attended prenatal services while pregnant, literacy rate, child age in years, household size square and non -poor parent.

Our result reveals that the instrument used is strong and relevance 
and so valid, following the weak identification test: Cragg-Donald F-Stat [5\% maximal IV relative bias] 416.961 [16.38] and the Sargan statistic (overidentification test of all instruments): (Chi-sq(2) P-val): 0.000 [0.000], further, the Durbin-Wu-Hausman test for exogeneity of variables in 7.455[0.0003] and wald test of exogeneity 4.57[0.0002] reveals that the problem of endogeneity is solve. The use of instrumental variable in our study has greatly reduced the effect of any bias that could have existed in our regression and so rendering our result robust.

\section{Child age in years and household water source effects}

Table 4 presents the result of household water source effects by child age in years according to the IVPROBIT model as seen from above. We observed that water supply does not affect children of $\leq 1$ year except otherwise. Knowledge of absolute breast feeding is widely vulgarized in Cameroon especially for the first six months of delivery. This means that in the first months of child delivery, mothers absolutely gives their children only breast mild they don't have any contact with water apart from bathing and watching the baby. In most cases the water used to bath the baby is not only boiled but heavily treated to avoid any form of infection.

The rural women in Cameroon have been noted of extending the breast feeding of their children to one year and below. Even those children whose parents attempt to give them water, it's usually treated water. Many hospitals have taken upon themselves to advise the mothers on the importance of water to the health of their children. Factors associated child health at age zero includes: the breast feeding mother, birth interval, male household head, parent social status and the literacy rate of parents. In the other hand the factors associated with child age one include the following: breast feeding mothers, fertility rate, prenatal care, birth interval, household size, social status and mothers currently working.
The health of child age 2 and 3 years old is strongly affected by source of water supply. Children of age two and three years old are difficultly controlled in rural Cameroon due to the nature of the environment and excitement on the part of the children to exercise their leg muscles in walking. It's widely observed that children attempting to walk really create much time to do it, given therefore the dirty and unsecure environment; the children can easily contract diseases roaming the environment either in drinking water or just standing water.

Most typical villages in Cameroon have earth floor that are usually characterize by dust, at times muddy in the rainy season, rough food particles, insect infested (termites, ants, house-fly) also water is constantly used to wet the floor to reduce the quantity of dust. All these create a favourable condition for insect growth and so affecting the health of the children 24 to 36 months old [19].

Other factors positively affecting children's health of age 24 to 36 months are household size and place of residence while factors negatively correlating with child health of age 24 to 36 months are: breast feeding mothers, mother currently working in the job market, prenatal care, birth interval, literacy and social status of the family. Child age 4 years and above is not affected by water supply. This result sound ambiguous, however, the reality in Cameroon holds that child age four is the school going age, most parents at that child's age begins treating the child as themselves or full functioning human being such that what they eat and drink is what the child eats and drink. In such an age children begin to learn even at school the importance and necessity of good drinking water. In most nursery and primary schools in Cameroon, the subject of hygiene especially drinking water is the centre of lectures /class notes being verbal or written, hence as tender the children might be, they begins to exercise some caution in what they drink or eat in both in and out of home. The result of this section is presented in Table 4 below.

\begin{tabular}{|c|c|c|c|c|c|}
\hline \multirow[t]{2}{*}{ Variable } & \multicolumn{5}{|c|}{ Probit model controlling for Endogeneity (IVPROBIT) } \\
\hline & $=0=$ & $=1=$ & $=2=$ & $=3=$ & $=4=$ \\
\hline Household Source of Water & $0.001(0.06)$ & $0.013(1.06)$ & $0.028^{\star \star}(2.07)$ & $0.041^{* \star *}(3.04)$ & $-0.019(-1.04)$ \\
\hline $\begin{array}{l}\text { Mother breast feeding ( } 1=\text { mother breast feed the child, } \\
0 \text { otherwise) }\end{array}$ & $-0.444^{\star * \star}(-3.91)$ & $0.197^{\star * \star}(4.53)$ & $-0.041(-0.75)$ & $-0.132^{* *}(-2.37)$ & $-0.031(-0.45)$ \\
\hline Fertility rate & $0.015(1.29)$ & $-0.063^{* * *}(-6.96)$ & $-0.003(-0.29)$ & $-0.000(-0.03)$ & $0.001(0.11)$ \\
\hline Participation ( $1=$ mother currently working, 0 otherwise) & $0.072(1.18)$ & $-0.128^{\star \star \star}(-2.64)$ & $-0.062(-1.15)$ & $-0.119^{* *}(-2.06)$ & $0.048(0.65)$ \\
\hline Marital status ( $1=$ mother is married, 0 otherwise) & $-0.012(-0.15)$ & $0.084(1.35)$ & $0.042(0.51)$ & $-0.036(-0.43)$ & $-0.053(-0.46)$ \\
\hline $\begin{array}{l}\text { Prenatal care ( } 1=\text { mother attended prenatal, } 0 \\
\text { otherwise) }\end{array}$ & $-0.109(-1.53)$ & $-0.261^{* * *}(-4.17)$ & $-0.235^{* * *}(-2.81)$ & $-0.232^{* *}(-2.01)$ & $-0.357^{* *}(-2.36)$ \\
\hline Birth Interval & $-0.003^{* * *}(-2.74)$ & $0.002^{* *}(2.28)$ & $0.000(0.02)$ & $-0.002^{* *}(-2.46)$ & $0.001(0.43)$ \\
\hline Male ( $1=$ male headed household, 0 otherwise) & $0.188^{* *}(2.58)$ & $-0.044(-0.76)$ & $0.028(0.38)$ & $-0.043(-0.57)$ & $0.142(1.43)$ \\
\hline Literacy ( $1=$ parent literate, 0 otherwise ) & $-0.174^{\star * \star}(-3.05)$ & $0.009(0.21)$ & $-0.199^{* * *}(-3.51)$ & $-0.185^{\star \star *}(-2.95)$ & $-0.390^{* \star *}(-5.28)$ \\
\hline Social status ( $1=$ parent non-poor, 0 otherwise) & $-0.230^{* *}(-2.45)$ & $-0.148^{*}(-1.95)$ & $-0.049(-0.45)$ & $0.076(0.71)$ & $-0.162(-1.34)$ \\
\hline Household size & $0.005(0.35)$ & $0.0495^{\star \star *}(4.09)$ & $0.041^{* *}(2.45)$ & $0.039^{\star *}(2.47)$ & $0.027(1.43)$ \\
\hline Household Size Square & $0.000(0.32)$ & $-0.001^{\star *}(-2.42)$ & $-0.001(-1.55)$ & $-0.001^{*}(-1.84)$ & $-0.000(-0.48)$ \\
\hline Household residence ( $1=$ urban residence, 0 otherwise) & $0.177(1.50)$ & $0.165(1.47)$ & $0.191^{*}(1.71)$ & $0.279^{* *}(2.17)$ & $-0.169(-1.02)$ \\
\hline Constant term & $-0.551(-1.14)$ & $-1.105^{\star * *}(-3.02)$ & $-1.505^{\star \star \star}(-4.08)$ & $-1.873^{\star *}(-5.30)$ & $-0.509(-0.81)$ \\
\hline $\begin{array}{l}\sigma \text { (Correlation of Birth weight Residual with Sample } \\
\text { Selection Residual), (Std. Err.) }\end{array}$ & $0.005(0.178)$ & $-0.138(0.152)$ & $-0.337(0.162)$ & $-0.516(0.159)$ & $0.213(0.208)$ \\
\hline$\sigma$ (Sigma of Birth Weight) (s.e) & $12.143(0.136)$ & $11.752(0.110)$ & $11.598(0.139)$ & $11.759(0.141)$ & $11.308(0.139)$ \\
\hline Wald test of exogeneity & $0.00(0.9765)$ & $0.81(0.3694)$ & $3.67(0.0053)$ & $6.91(0.0086)$ & $0.98(0.3216)$ \\
\hline Wald chi2 & $82.07((13 ; 0.0000)$ & $153.19(13 ; 0.0000)$ & $122.92(13 ; 0.0000)$ & $104.77(13 ; 0.0000)$ & $80.47(13 ; 0.0000)$ \\
\hline Observations & 3957 & 5671 & 3467 & 3462 & 3300 \\
\hline
\end{tabular}

Source: Computed by author using pooled data of 2004/2011 survey and STATA 11.0 .

Notes: ${ }^{* * *},{ }^{* *}$ and ${ }^{*}$ indicate $1 \%, 5 \%$ and $10 \%$ levels of significance. N/B: Dependent variable is child ill/death due to diarrhea diseases; values are in three significant figures; absolute value of robust t-statistics in parentheses beneath estimates.

Table 4: Decomposition of water source effects by child age in years. 
Citation: Tambi MD (2017) Linking Household Source of Water to Child Health Technology: Evidence from 2004-2011 Cameroon Demographic and Health Survey. Int J Econ Manag Sci 6: 486. doi: 10.4172/2162-6359.1000486

Page 8 of 8

\section{Conclusion and Policy Implications}

Understanding the intricacies underlining the effects of household source of water on child health outcomes as well as other factors determining child health in an era of high infant death rate especially in a developing country like Cameroon is critical for public policy and debate that highlight infant survival rates to be grounded by evidencebased research. These issues are particularly useful in the context of economic growth and poverty reduction in the different regions under public health and increase well-being of households. Such knowledge would help reduced child death rate and inequality, increase household asset endowment, increase maternal labour force participation as time is redeem in going to stay with child in the hospital because of ill health, money is also save which increases standards of living.

To bridge this gap we examined the following objectives: (1) the impact of household source of water on child Health outcomes in Cameroon; (2) decompose the effects of water source in child age 0 to 59 months; (3) derive policy implications on the basis of our analysis. We used the IVPROBIT model to estimate our 2004/2011 Cameroon DHS in STATA 11.0.

We observed that factors such as parent literacy, breast feeding mothers, male household head; household social status, household size and urban residence are strong determinants of household source of water. However, parent literacy, breast feeding mothers, male household head are positively correlating with household water supply while household social status especially non-poor households, household size and urban residence are factors negatively correlating with water source.

We also observed that a marginal change in water supply will result to a corresponding increase in child health of $1.5 \%$. The other factors positively associated with child health increase due to water effects include: household size, urban household residence, while factors negatively associated with child health are; mothers currently employed in the job market, breast feeding children, fertility rate, mother attended prenatal services while pregnant, literacy rate, child age in years, household size square and non -poor parent. The health of child age 24 and 36 months is strongly affected by source of water supply. Other factors positively affecting children's health of age 24 to 36 months are household size and place of residence while factors negatively correlating with child health of age 24 to 36 months are: breast feeding mothers, mother currently working in the job market, prenatal care, birth interval, literacy and social status of the family.

In terms of policy, we recommend that decision makers in Cameroon through the ministry of public health should intensive child-water hygienic campaigns, while the government strategizing to increase the supply of good drinking water following the WHO standards. This is a major step towards economic growth and poverty reduction in the different regions under public health and increase well-being of households.

\section{References}

1. Tambi D M (2014) Modeling the Effects of Mother's Age at First Birth on Child Health at Birth. Asian Journal of Economic Modelling 2: 1-17.

2. WHO (2014) Burden of disease and cost-effectiveness estimates. World Health Organization.

3. UNICEF (2008) Why improved sanitation is important for children, UNICEF/ HQ06-1838.

4. Pruss-Ustun A, Bos R, Gore F, Bartram J (2008) Safer water, Better Health Costs Benefits and Sustainability of interventions to protect and promote health, Geneva-WHO 2008

5. Cheng J, Schuster C, Watt S, Newbold B, Mente A (2012) An ecological quantification of the relationships between water, sanitation and infant, child, and maternal mortality. Environmental Health 11:4.

6. Bampoky C (2013) Can clean water and sanitation reduce child mortality in Senegal? Repperdine Policy Review 6.

7. Sambe-Ba B, Emmanuelle EE, Faye E, Timbiné L, Sembene M, et al. (2013) Community-acquired diarrhea among children and adults in urban settings in Senegal: clinical, epidemiological and microbiological aspects. BMC Infect Dis. 13: 580

8. Schiller LR (2007) Management of diarrhea in clinical practice: strategies for primary care physicians. Rev Gastroenterol Disord. 13: 27-38.

9. GOC (2011) Government of Cameroon, global gender gap - country profile report, $23^{\text {rd }}$ September, 2011.

10. Ndze N, Akum E, Kamga N, Enjema E, Esona D et al. (2012) Epidemiology of rotavirus diarrhea in children under 5 years in Northern Cameroon. Pan African Medical Journal 11: 73

11. Ntouda J, Sikod F, Ibrahim M, Abba I (2013) Access to drinking water and health of populations in Sub-Saharan Africa. Comptes Rendus Biologies 336: 305-309.

12. Aryal K, Joshi HD, Dhimal M, Singh SP, Dhakal P, et al. (2012) Environmental burden of diarrhoeal diseases due to unsafe water supply and poor sanitation coverage in Nepal. Journal of Nepal Health Research Council 10:125-129.

13. Roushdy R, Sieverding M, Radwan H (2012) The Impact of Water Supply and Sanitation on Child Health: Evidence from Egypt, 2012 The Population Council Inc.

14. Moe C, Sobsey M, Samsa GP, Mesolo V (1991) Bacterial indicators of risk of diarrhoeal disease from drinking-water in the Philippines. Bull World Health Organ 69: 305-317.

15. Gundry S, Wright J, Conroy R (2004) A systematic review of the health outcomes related to household water quality in developing countries. Journal of Water Health 2:1-13.

16. Becker (1965) A theory of the allocation of time. The Economic Journal 75 493-517.

17. Frijters P, David WJ, Manisha S, Michael A (2008) To Work or Not to Work? Child Development and Maternal Labor Supply. American Economic Journal: Applied Economics 1:97-100.

18. Wooldridge JM (1997) On two stage least squares estimation of the average treatment effect in a random coefficient model. Economics Letters 5: 129-133.

19. Bastian S (2009) Drastic consequences of diarrhoeal disease Current Opinion in Biotechnology 15: 175-180. 